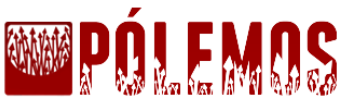

\section{MINHAS MEMÓRIAS COM FREI MATEUS DA ROCHA: UM TESTEMUNHO. ${ }^{1}$}

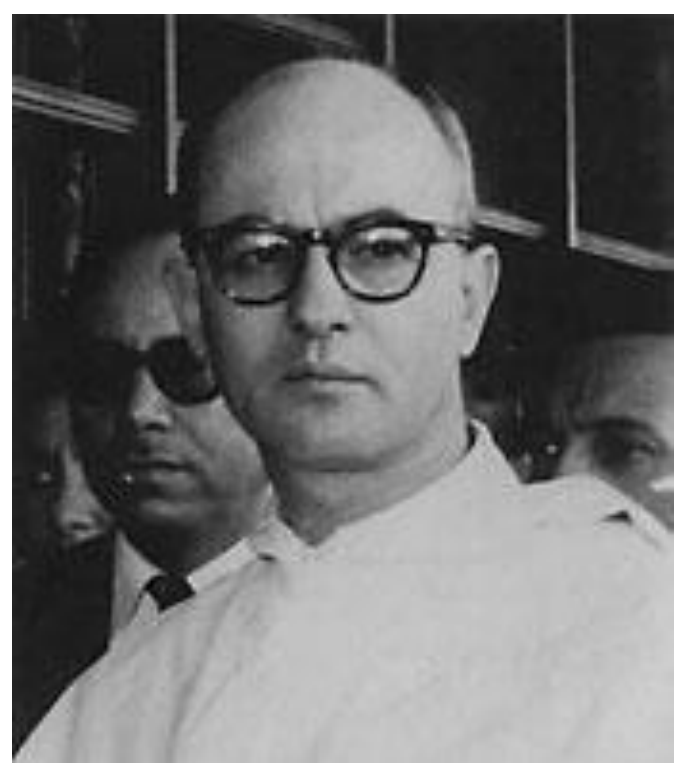

Frei Mateus da Rocha ${ }^{2}$

Antônio Muniz de Rezende amurez@yahoo.com.br Universidade Estadual de Campinas - UNICAMP

Gostaria de começar agradecendo. Ao Márcio [Gimenes de Paula, organizador do evento, docente do FIL UnB], pelo convite que me fez. Ao Alex [Calheiros de Moura, docente do FIL UnB], pela indicação de meu nome. A todos os colegas, por sua rica contribuição. E o faço, porque minha participação nesse encontro me fez muito bem. Em todos os sentidos. Mas principalmente porque me permitiu reviver, na

\footnotetext{
${ }^{1}$ Tal artigo foi, originariamente, uma palestra apresentada no evento "Frei Mateus Rocha, pioneiro da UnB", no dia 24 de setembro de 2012, em Brasília.

${ }^{2}$ Vale lembrar que Frei Mateus foi reitor da UnB entre 1962 e 1963 e vice-reitor na gestão de Anísio Teixeira nos anos seguintes, até a instauração da ditadura militar em 1964. Fonte: http://www.unb.br/administracao/reitoria/exreitores/mateus rocha. Nota do editor.
} 
lembrança, momentos e períodos muito significativos de minha própria vida. Inclusive, porque houve agradável coincidência na abordagem adotada pelo Warton ${ }^{3}$ e a minha.

Aliás, gostaria de relembrar alguma coisa que disse hoje de manhã, e me parece importante para todos, especialmente para o Warton e para mim. Acho indispensável distinguir duas gerações (ou mesmo três): por um lado a do frei Mateus, por outro a do Betinho e do Warton, por último a do frei Betto, do Tito, do Fernando e do Osvaldo. Usando uma linguagem freudiana, eu quase diria que a segunda e terceira gerações viveram seu édipo de maneira muito especial. Não vou chegar ao ponto de dizer que houve algum atentado contra o pai, absolutamente! Mas houve, digamos assim, um novo encaminhamento, por parte das novas gerações. Não quero insistir demais, porque vocês poderiam pensar que nós seríamos os velhos e eles os novos! Não é bem isso. Como o Warton acabou de dizer, frei Mateus era uma pessoa inovadora em muitos sentidos. E quanto a mim, posso dizer o seguinte: frei Mateus era um pouco mais velho que eu (no ano que vem ele completaria 90 anos e eu vou fazer 85 !), mas nós tínhamos uma relação fraterna e amigável muito especial. Por isso mesmo, vou ver se consigo transmitir a vocês um pouco das características do Mateus, características pessoais, bem marcantes, a ponto de tornarem-no inesquecível para todos os que o conheceram.

Vou começar dizendo que frei Mateus era mineiro. Mineiro, não apenas no sentido geográfico, mas naquele sentido em que, por exemplo, Alceu de Amoroso Lima escreveu este belíssimo livro sobre A voz de Minas. Há, por assim dizer, uma "mística" na vocação de Minas Gerais, que vem desde a Inconfidência Mineira. Aliás, me disseram, outro dia, uma coisa, interessante que, se não é vera é pelo menos benetrovata: nós mineiros gostamos de repetir UAI! O que me disseram é que UAI significa União dos Amigos da Inconfidência! "Si non è vero, è bene trovato!" Nós herdamos a bandeira dos Inconfidentes.

E o próprio Tristão de Athayde escreveu seu livro num certo contexto (em 1944), um ano antes de Getúlio Vargas chegar ao fim de um longo período que, significativamente para mim, começou quando nasci (em 1928)! Um período que, igualmente, faz parte da história da Igreja Brasileira, por exemplo, conotando a convivência do Tristão com Jackson de Figueiredo.

Qual a característica pessoal do Jackson? A que o levou a criar o "Centro Dom Vital" e a revista A Ordem, em grande parte inspirado no Cardeal Leme que, na época,

\footnotetext{
${ }^{3} \mathrm{O}$ prof. Warton Monteiro (UnB) também ministrou palestra nesse mesmo evento e acompanhava, na ocasião, o autor do presente artigo.
} 
fazia um evidente aceno na direção de uma Igreja renovada. E qual era a renovação proposta a que também frei Mateus aderiu?

No contexto da renovação da Igreja, frei Mateus, tendo nascido em Dom Silvério, mudou-se primeiramente para o seminário secular de Mariana. Em seguida, foi para o seminário dos padres Lazaristas em Petrópolis. Finalmente, foi para o convento dos Dominicanos, em São Paulo. Esta é a caminhada de frei Mateus: de Minas, passando pelo Rio, para chegar a São Paulo, ao encontro dos Dominicanos que, na ocasião, eram conhecidos como "dominicanos franceses."

O que isso significava no contexto brasileiro? Significava, por exemplo, uma familiaridade maior com o filósofo francês Jacques Maritain, de quem Alceu de Amoroso Lima era amigo. Eu vivi essa época junto com frei Mateus, e nós tínhamos na figura do Jacques Maritain uma espécie de bandeira para um pensamento filosóficocristão em continuidade com uma teologia tomista renovada. Qual a renovação, na época, para nós? A visão de uma Igreja presente, na forma de uma cristandade participante e atuante.

Isso significava de fato, tanto no Brasil como na França, uma perspectiva de militância que preparasse, digamos assim, um engajamento consequente na vida política do País. Não sei se você se lembra, Warton, mas na época que você mencionou ao falar da JEC (Juventude Estudantil Católica), os jecistas, que portanto ainda estavam no secundário ou colegial, já viviam um momento de escolha da profissão, olhando longe, e se perguntando como atuariam futuramente na vida política do País. Por exemplo, eles se perguntavam: dentre nós aqui (na JEC) quem vai ser o futuro Ministro da Educação? Quem vai ser o futuro Ministro do Trabalho? Dessa forma, eles começavam a fazer uma opção profissional e política, na passagem da JEC para a JUC (Juventude Universitária Católica), do secundário para a universidade. Isso era levado muito a sério, e muito respeitado, a tal ponto que, se não me falha a lembrança, o Betinho devia preparar-se para ser o futuro Ministro da Justiça! Isso não era para ser divulgado e ficava como uma (in)confidência secreta, que não dispensava ninguém de ir se preparando desde então, principalmente na passagem da JEC para a JUC.

Frei Mateus nasceu em Minas, foi para os Dominicanos em São Paulo, e de São Paulo foi para a França. A esse propósito quero completar algumas informações que o Warton já lhes deu. Circunstancialmente, eu fui para a França antes do frei Mateus, porque já estava nos Dominicanos antes de ele chegar. Fui para a França em 48, um pouco depois do fim da guerra em 45, e ainda pude participar do clima característico do pós-guerra. Um clima e uma situação muito bem descritos por Jean-Paul Sartre nos 
termos de uma "angústia existencial". Isto mesmo me ajudou muito a perceber como o existencialismo sartreano não era, nem podia ser, principalmente teórico. Por exemplo, a angústia existencial francesa tinha tudo a ver com o exército alemão desfilando em frente ao Arco do Triunfo. Cadê o Triunfo da França? Em vez de triunfo era a derrota e a humilhação!

Quando cheguei à França, em 48, ainda havia esse clima de angústia existencial desafiando todos os franceses a uma reconstrução da consciência nacional e do sentido da existência. Para mim, até hoje, fica muito fácil ler o Sartre dessa época e entender o desafio que se colocava a todos nós. A meu modo eu também vivi esse desafio. O Mateus também, logo depois.

Quando ele e eu chegamos lá para estudar teologia, havia alguns nomes significativos. Um deles era o do Père Chenu, outro do Père Congar, ambos Dominicanos; sem esquecer o Père Daniélou e Henri de Lubac, ambos Jesuítas. Os dois primeiros do Saulchoir, (bem como o Père Daniélou), eram especialistas na nova eclesiologia, e publicavam uma revista, que nós designávamos como RSPT (Revue des Sciences Philosophiques et Théologiques). E nas vizinhanças do Saulchoir, no EauVive, como um centro de teologia mística, eu pude assistir a um curso ministrado por Jacques Maritain com o título "Neuf leçons sur la philosophie morale", com ênfase no papel da ética na vida social e política.

Um pouco mais longe, em Lyon, aparecia o Père Joseph Lebret que não demorou a fundar o movimento "Economia e Humanismo", num corajoso diálogo com o marxismo. Desse movimento, frei Benevenuto e frei João Batista tornaram-se representantes no Brasil. O primeiro, fundando a livraria Duas Cidades, o segundo fundando a Unilabor ${ }^{4}$ como experiência de uma comunidade de trabalho.

O mais importante para nós que ainda éramos estudantes de teologia era termos como mestres Padre Chenu e Padre Congar, como lideres de um pensamento renovado

\footnotetext{
${ }^{4}$ Apenas para situar o leitor, sem nenhuma outra pretensão, segundo a Enciclopédia de artes do Itaúcultural: "A Unilabor é uma fábrica de móveis modernos que funciona na cidade de São Paulo, no bairro operário do Ipiranga, entre 1954 e 1967. A empresa integra - e viabiliza financeiramente - a Comunidade de Trabalho Unilabor, um projeto social-religioso conduzido pelo frei dominicano João Batista Pereira dos Santos com o apoio de empresários, intelectuais e artistas. Entre os colaboradores, destaca-se Geraldo de Barros, responsável pelo desenho dos móveis Unilabor. Além do engajamento de agentes culturais no empreendimento, a principal característica do projeto é a autogestão operária com lucros partilhados entre os funcionários." Fonte:http://www.itaucultural.org.br Há ainda um livro publicado sobre a experiência: CLARO, M., Unilabor: Desenho industrial, arte moderna e gestão operária. São Paulo: Senac, 2004. Nota do editor.
} 
na Europa. No Saulchoir, uma eclesiologia renovada; em Saint Maximinna Provence, principalmente com os padres Labourdette, Jean Nicolas, e Leroy, uma leitura renovada da obra de Santo Tomás de Aquino. A Revue Thomiste era o instrumento de sua divulgação, na forma de uma leitura séria dos teólogos tomistas bem como dos textos de Aristóteles, na prática de uma filosofia aristotélico-tomista atualizada.

Com isso se fazia uma tentativa de recuperar o que havia de melhor na contribuição dos teólogos da Idade Média, com as primeiras universidades (a começar pelas de Bolonha e Paris), sem esquecer os nomes de Alberto Magno e Mestre Eckhart na Alemanha (um pouco menos escolásticos). A este propósito, um outro nome a ser lembrado é o de Etienne Gilson. É dele essa frase a respeito do obscurantismo da Idade Média: "Na realidade, o que se vê é o obscurantismo daqueles que desconhecem a Idade Média".

Pois bem, é com essa mentalidade, digamos, "francesa renovada", que frei Mateus voltou ao Brasil, e aqui encontrou a Ação Católica como precioso instrumento de "ação", a partir de uma presença atuante nos diversos meios, com vistas ao que em seguida se chamou de "Revolução Brasileira". Inspirada inicialmente na JOC, (Juventude Operária Católica) a Ação Católica passou espontaneamente a falar de JAC (Juventude Agrária Católica), de JEC (Juventude Estudantil Católica), de JIC (Juventude Independente Católica), e de JUC (Juventude Universitária Católica). Uma nomenclatura parecida foi usada para os mais velhos que se diziam "Homens da Ação Católica".

Junto aos mais velhos, atuavam, entre os Dominicanos, o frei Rosário Joffily, frei Romeu Dale, frei Reginaldo de Sá, frei Pedro Secondi, bem como frei Sebastião Tauzin. E dentre os "homens" que frequentavam o convento das Perdizes (Rua Caiubí, 126), eu me lembro especialmente de André Franco Montoro, Paulo de Tarso, o pai do Plínio de Arruda Sampaio, Francisco Whitaker e outros já engajados politicamente.

Neste mesmo contexto, situa-se frei Carlos Josaphat Pinto de Oliveira, com seus cursos sobre a doutrina social da Igreja, e, em seguida, a fundação do jornal "Brasil Urgente". Os cursos lotavam a igreja, frequentados por militantes jovens e mais velhos, numa conscientização que logo começaria a dar frutos na forma de um engajamento responsável e participante. A Nação Católica Brasileira naquele contexto tinha por assim dizer como motivação maior, a Revolução Brasileira, muito mais à esquerda do que à direita. (Eu mesmo, nesta ocasião, fundei o movimento conhecido como CJC, ou Comunidade de Jovens Cristãos, numa tentativa de viver o espírito comunitário no âmbito das Comunidades Paroquiais. A este propósito escrevi Cristianismo e Juventude, 
publicado pela Duas Cidades). E em Belo Horizonte o Padre Vaz tornava-se conselheiro particular dos fundadores da Ação Popular, numa tentativa de ir além da Ação Católica. E, a seu tempo, Dom Tomás Balduino, bispo dominicano da cidade de Goiás, veio a ser líder da Pastoral da Terra, até os dias de hoje.

É nesse contexto que se situa, digamos assim, um novo encontro de mineiros, entre o frei Mateus, o Darcy Ribeiro e o próprio Juscelino Kubitschek. Eu diria que a Revolução Brasileira em termos mineiros, era uma retomada da Inconfidência, tendo em comum com ela uma tomada de posição contra o capitalismo internacional. No caso da Inconfidência, o ponto de partida foi a recusa de pagar o "quinto" do dinheiro arrecadado nas minas de ouro. O capitalismo colonialista vem desde esse tempo, quando o Brasil teve que pagar uma dívida que Portugal tinha com a Inglaterra.

Um pequeno detalhe anedótico, que me diz respeito, é o seguinte. Meu pai nasceu em uma cidadezinha do Triangulo Mineiro que, naquela época, chamava-se Bagagem. Esse nome foi mudado para Estrela do Sul, ali perto do rio Paranaíba. Por que esse nome? Porque ali foi encontrado o maior diamante brasileiro até àquela época. Aonde é que ele se encontra? Nos tesouros da Rainha da Inglaterra!

Isto é, nós, não apenas, com D. João VI, tivemos que pagar a dívida de Portugal, mas continuamos sendo explorados pelo capitalismo internacional até na forma da garimpagem. Nós garimpávamos para a Inglaterra!

Bem, agora vou me permitir dar a palavra ao próprio frei Mateus. Eu tinha conversado com o Warton no sentido de tentarmos dar a vocês não só uma imagem bonita como a que está no cartaz do evento, mas se possível transmitir-lhes até mesmo seu tom de voz. Não sabendo eu imitar o tom de voz do frei Mateus, contento-me em ler uma página escrita por ele. Aliás, prometi ao Alex e ao Marcio que vou fazer um Xerox deste capítulo publicado neste livro sobre Os Dominicanos ${ }^{5}$. Na capa uma gravura feita pelo pintor Emeric Marcier. Ele morou em Barbacena, um pouco depois do Georges Bernanos: ambos representando a nova arte, tanto em literatura como em pintura.

Eis o texto de frei Mateus que lhes queria ler:

Passaram-se quase 20 anos. Hoje quando recordo todos esses acontecimentos, sobretudo quando procuro reviver o clima em que foram vividos, a sensação que permanece é a de um país em movimento. Iniciara-se um processo revolucionário, perigoso sem dúvida, mas que certamente não tinha condições internas nem externas para desembocar no socialismo. E fico pensando com os meus botões que se tivesse vingado talvez nos tivesse conduzido a um

\footnotetext{
${ }^{5}$ ROCHA, Mateus. “A Província Dominicana do Brasil: evocações” In Os Dominicanos, pp. 169-184, Monjas Beneditinas do Mosteiro da Santa Cruz, Juiz de Fora, 1981.
} 
desenvolvimento de cunho mais nacionalista e a uma forma de democracia mais avançada em que o povo pudesse de fato participar da vida e do destino do país. Tudo isso com uma grande influência da igreja. São conjecturas, apenas conjecturas. Por certo as forças conservadoras foram mais poderosas, as forças de renovação ainda estavam verdes e mal equipadas para assumir a tarefa com que a história lhes acenava. Pode ser que o Brasil tenha perdido uma grande chance histórica. (ROCHA, 1981, p.178)

E aqui começa um outro parágrafo:

E tudo mudou. Um contexto em que eclodiu a contra-revolução de março de 64 (ROCHA, 1981, p.178).

Agora eu interrompo a leitura e retomo minha própria fala. Brasília nasceu, eu diria, à luz de um projeto de interiorização da capital por motivos que ainda tinham a ver com possíveis ameaças externas. Vindo para o Brasil Central, procedia-se a uma interiorização da capital, proporcionando ao mesmo tempo maior desenvolvimento da região. E o Darcy Ribeiro aparece nesse momento com suas ideias de antropólogo. Acho importante insistir no fato de o Darcy ser um antropólogo que já havia estudado as características do "povo brasileiro". E não é de admirar que o Presidente Juscelino o tenha escolhido para pensar na fundação da UnB, no coração do Novo Brasil.

Um aspecto correlato do que eu disse a respeito da JEC e da JUC, antecipando a escolha de uma profissão, é que no modelo adotado pelo Darcy para a UnB, haveria um “curso básico" pelo qual deveriam passar todos os alunos. Aos poucos, depois de dois ou três anos, é que os alunos iriam escolhendo uma profissão definitiva. (Esse mesmo modelo foi adotado, pelo menos em parte, pelo prof. Zeferino Vaz, quando da fundação da Unicamp).

Do ponto de vista da Igreja, tudo isso acontecia contemporaneamente ao Concílio Vaticano II com o Papa João XXIII, a tal ponto que esse Concílio foi considerado e chamado o "Concílio da Esperança". Qual sua grande inspiração, ou melhor, qual a grande proposta do João XXIII? O que se chamou, na época, de "fim da era constantiniana", com explícita referência ao Imperador Constantino, primeiro imperador cristão.

O que isso significa? Confesso que só vim a entender todo o alcance da referência a Constantino quando recentemente visitei Istambul, capital da Turquia, antiga Constantinopla, fundada pelo Imperador Constantino no século IV. Sua conversão ao cristianismo ocasionou uma mudança extraordinária para os cristãos. Até então, eles viviam nas catacumbas, para evitar as perseguições. Com a conversão do 
Imperador, os cristãos não apenas saíram das catacumbas, mas Roma se tornou a capital do cristianismo. Em seguida, com a fundação de Constantinopla, surgiu uma discussão importante a respeito de saber se a capital continuaria sendo Roma ou passaria a ser Constantinopla.

Acho esse aspecto importante até hoje. Hoje de manhã nós falamos sobre ciências da religião, com alguma ênfase na história. Pois bem, um aspecto extremamente sério é quando nos referimos à "civilização ocidental cristã" ou então à “civilização judeo-greco-romana", com suas consequências tanto de ordem filosóficoteológica, como sócio-política. Um exemplo eloquente é quando acompanhamos as mudanças de vocabulário, tanto em filosofia como em teologia. Por exemplo, a "palavra" em hebraico é "dabar", em grego é "logos", em latim é "verbum".

O pensamento religioso exprimia-se nestas palavras conotando toda uma semântica existencial. Por exemplo, o "dabar" hebraico significava uma palavra de Deus que se fazia história, uma História do Povo de Deus, conotando o papel dos profetas como intérpretes dos acontecimentos. Com a diáspora e a evangelização dos países de língua grega, o Dabar-histórico, passou a ser Logos-Transcendente, como dito por São João no início de seu Evangelho: "Enarquêho Logos...". O pensamento religioso hebraico tornou-se um pensamento religioso grego (muito próximo da filosofia). Por último, Dabar e Logos, tornaram-se "Verbum", numa latinização não só da linguagem, mas do pensamento: o mesmo pensamento que posteriormente deu nascimento ao Direito romano, e sustentação política ao Império Romano.

O principal aspecto que nos interessa é que, virando romano, o cristianismo viu seu destino associado ao do Império. No De Bello Galico Cesar descreveu o processo através do qual o Império dilatou suas fronteiras não só até à Gália, mas também até Portugal. Situação esta que também Camões voltou a cantar n'Os Luzíadas, ao falar dos Navegadores que partiam de Portugal "Dilatando a fé e o Império"!!!!

Evidentemente, desta forma, passou a haver um acoplamento da história do Cristianismo com a do Império Romano em suas diversas expansões. Os navegadores portugueses, que foram para a Ásia, que vieram para a América Latina, e para o Brasil, estavam ao mesmo tempo dilatando a Fé e o Império. E eu digo isso pensando em outras viagens que fiz, por exemplo, até à cidade do México. Quando lá estive pela primeira vez, fiz duas visitas mais importantes: uma à catedral, outra ao Museu de Antropologia. Na catedral, eu fiquei sabendo que tinha sido literalmente construída em cima do palácio dos Astecas. Noutras palavras, uma civilização em cima da outra! E ao visitar o Museu de Antropologia me surpreendi ao constatar como os astecas tinham se 
desenvolvido principalmente em arquitetura e astronomia. E fico pensando até hoje, como seria a civilização Asteca, a civilização Inca, a civilização Maya, hoje, se não tivessem sido destruídas pela civilização ocidental cristã!

Num outro cruzeiro que fiz pelo Mediterrâneo, onde quer que o navio parasse, era para visitarmos as ruínas que ficaram depois da passagem do exército romano. E os estudiosos da língua latina certamente não esqueceram a frase "exemplar" que nos era ensinada: "Delenda Carthago". Cartago deve ser destruída!!!

Pois bem, tudo isso teve consequências até o Concílio Vaticano II, com João XXIII anunciando o fim da era constantiniana, em que "a fé e o império" estiveram intimamente ligadas e interdependentes. Era, portanto, o Concílio da Esperança, cuja consequência seria de um lado a liberdade religiosa da Igreja, e de outro uma inteligente secularização do Estado.

Mas, como muito bem lembrou o Warton, o Concílio prometeu muito mais do que de fato realizou - por uma espécie de sabotagem dos próprios membros da Cúria Romana. Eu acho que vocês também acompanharam isso: nós estávamos cheios de esperança nas promessas do Concílio Vaticano II, mas houve grande decepção, porque o prometido não pôde realizar-se. Foi uma decepção diante do fracasso provocado pela reação das forças conservadoras. Um fracasso que se transformou em desafio para todos nós, até hoje. E a reorganização do Instituto de Teologia da UnB talvez seja um dos aspectos de semelhante desafio, em terras brasileiras.

Quem fala de tudo isso de maneira mais ampla é o Luc Ferry em um livro intitulado A Tentação do Cristianismo. Título feliz porque pode ser interpretado tanto em sentido objetivo como subjetivo: as tentações a que o Cristianismo de hoje está exposto, e a tentação que o cristianismo ainda pode significar para muitos. Em termos históricos o Vaticano aconteceu prometendo (tentadoramente) muito mais do que realizou. E, no entanto, suas promessas não chegaram a ser esquecidas e continuam tentando muitos esperançosos até hoje. O Vaticano II, e João XXIII, não deixaram de estimular nossa criatividade. E o frei Mateus viveu tudo isso.

Um aspecto para o qual eu queria chamar a atenção de todos é o que se poderia chamar de dialética-mística dos homens com Deus. Um outro livro escrito por frei Mateus tem por título Projeto de vida radical. Nele, eu vejo frei Mateus proclamando e nos convidando a uma espécie de fé inabalável. Uma fé que o fazia viver essa mística não só do Deus Pai, mas dos Homens Irmãos. Uma fé em Deus e nos Homens de maneira radical. Uma mística-dialética de Deus Pai e dos Homens Irmãos. 
Como meu tempo se esgotou, eu queria terminar usando uma metáfora simbólica: frei Mateus morreu na estrada. Ele estava vindo de Abadiana, e a estrada não era tão boa quanto hoje. Em sentido contrário vinha um ônibus, e atrás do ônibus, um caminhão. De repente o caminhão quis ultrapassar o ônibus. Acelerou, e veio bater de frente no carro do frei Mateus. Ele morreu na hora.

Eu acho essa metáfora lindíssima, apesar de trágica. E ele resumiu tudo isso para mim na dedicatória de um outro livro seu, que ele me ofereceu. Ouçam a dedicatória:

Rezende, a certa altura da vida o Senhor nos conduziu por caminhos diferentes. Tudo é graça e os caminhos do Senhor convergem todos para o mesmo Reino de Deus, Frei Mateus.

Para mim está sendo uma alegria estar aqui com vocês, para homenagear frei Mateus, revivendo pelo menos na lembrança uma amizade e uma fraternidade que me comovem até hoje. Quis dar esse meu testemunho, que já tinha preparado antes mesmo de ouvir as outras palestras. Foi uma alegria reconfortante poder transmitir a vocês um pouco de minha intimidade com um homem que me parece extremamente rico na sua vitalidade, na sua amizade e nos seus gestos de atenção para com todos.

Se tiver conseguido transmitir-lhes um pouco desse outro lado do frei Mateus, eu vou ficar muito contente. E ficar também muito grato pela atenção de vocês.

\section{DEBATE}

$\mathrm{P}$ - O senhor veio conhecer o nascente Instituto de Teologia da UnB e iria trabalhar nele? 
R - Nós viemos, eu e vários colegas, conversar com o frei Mateus e ele repassava para o Darcy, a respeito do que poderia vir a ser a estrutura epistemológica do Instituto. Nessa ocasião, eu tinha defendido uma tese em Roma e trouxe um exemplar para o frei Mateus ver. Um outro colega que veio foi o Lepargneur, jovem teólogo francês que veio trabalhar no Brasil. Mas a inspiração básica, para todos nós, naquela época, era o modelo apresentado pelos teólogos franceses que mencionei acima: Congar, Chenu, Labourdette (cujos nomes podem ser pesquisados no Google). De fato, frei Mateus não teve tempo de apresentar uma estrutura do Instituto em termos de disciplinas a serem ministradas.

$\mathrm{P}$ - Era um investimento?

$\mathrm{R}$ - Houve sim uma antecipação, digamos a partir dos modelos europeus. Por exemplo, haveria uma ênfase na eclesiologia, na ética em relação com a sociedade, na história das religiões e na pastoral. Mas de início a ênfase era mesmo no modelo francês adaptado segundo nossas próprias necessidades.

$\mathrm{P}$ - Era grandioso do prédio do Instituto de Teologia?

R. O Agnaldo [Cuoco Portugal, docente do FIL UnB] me levou até lá para eu ver. De início me pareceu o mesmo prédio, do mesmo tamanho. Depois, rememorando e vendo fotografias da época, percebi que houve uma mudança importante. O Instituto propriamente era a parte central, com largas colunas um pouco arredondadas. Depois foram acrescentadas as partes mais baixas, na horizontal, de sorte que o prédio inicial ficou bem mais comprido. Não me lembro se o Instituto propriamente dito foi projetado pelo Oscar Niemeyer ou pelo Lelé [João Filgueiras Lima]. Era grandioso e sóbrio, ao mesmo tempo. De linhas puras. 


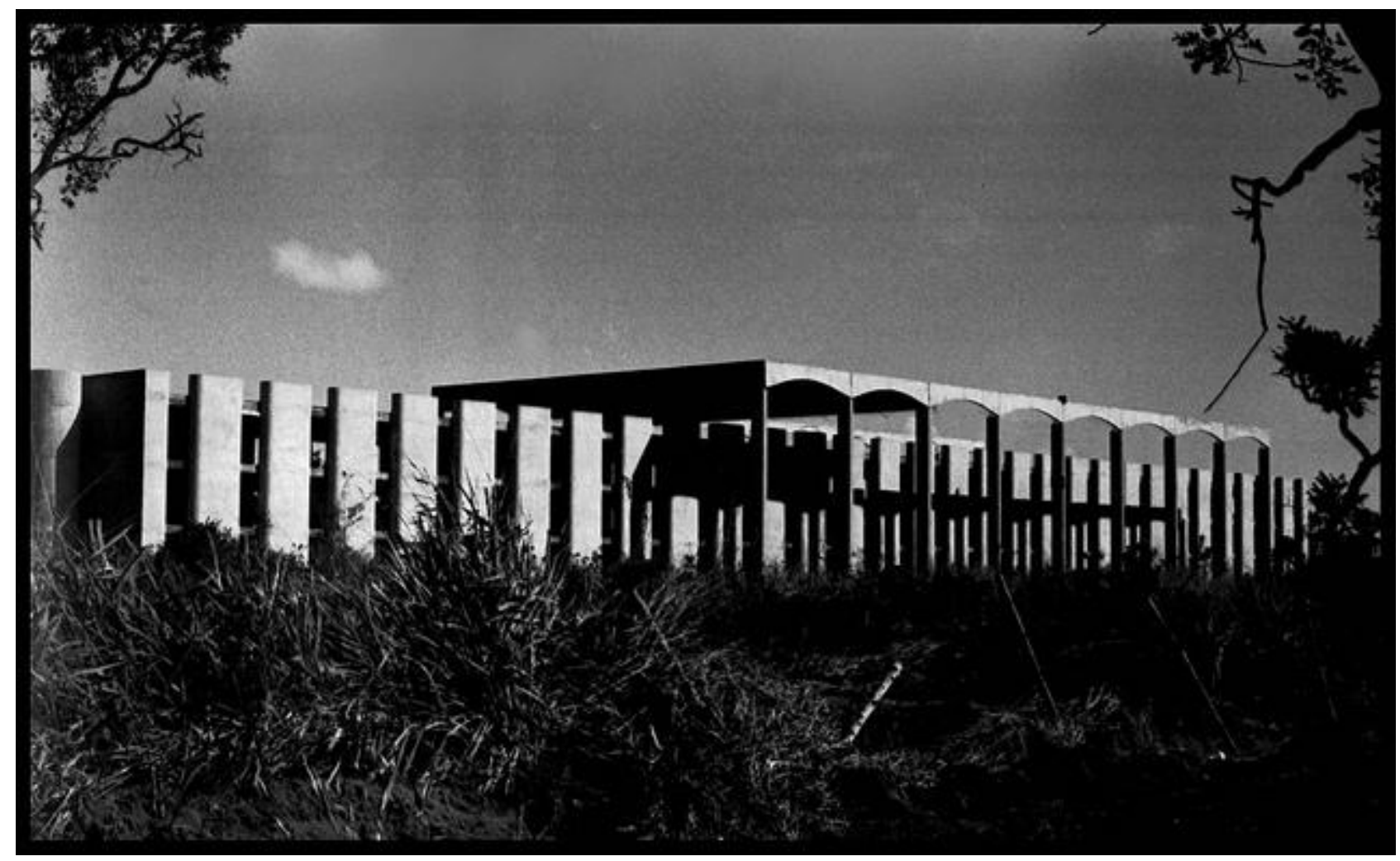

Instituto de Teologia - UnB. Projeto de Oscar Niemeyer e desenvolvimento de João Filgueiras Lima - Lelé (1963) 6 .

$\mathrm{P}$ - Em quais circunstâncias o projeto foi concebido?

$\mathrm{R}$ - O projeto se não foi compartilhado pelo Darcy, foi certamente discutido com ele. As dimensões correspondiam às diversas funções que deveria ter: salas de aula, biblioteca, anfiteatro, mas também capela, e eventualmente habitação dos professores.

$\mathrm{P}-\mathrm{Quais}$ seriam as disciplinas?

$\mathrm{R}$ - A ênfase seria na eclesiologia e na pastoral, com as disciplinas complementares, visando uma presença atuante na realidade brasileira.

P - A expectativa da implantação de um instituto hoje já não é fácil para nós, como era nessa época?

\footnotetext{
${ }^{6}$ Cf VILELA JUNIOR, Adalberto José. A casa na obra de João Filgueiras Lima. Dissertação de Mestrado em Arquitetura - FAU-UnB, 2010; FISCHER, S.; SCHLEE, A. Guia das obras de Oscar Niemeyer-Brasília 50 anos. Brasília: Instituto dos Arquitetos do Brasil/Câmara dos Deputados, 2010. Infelizmente, não encontramos o nome dos fotógrafos para dar o crédito das fotos.
} 
$\mathrm{R}$ - Eu não hesitaria em dizer que se tratava também de elaborar e fundamentar uma teologia da revolução brasileira, tal como a entendíamos antes de 64 .

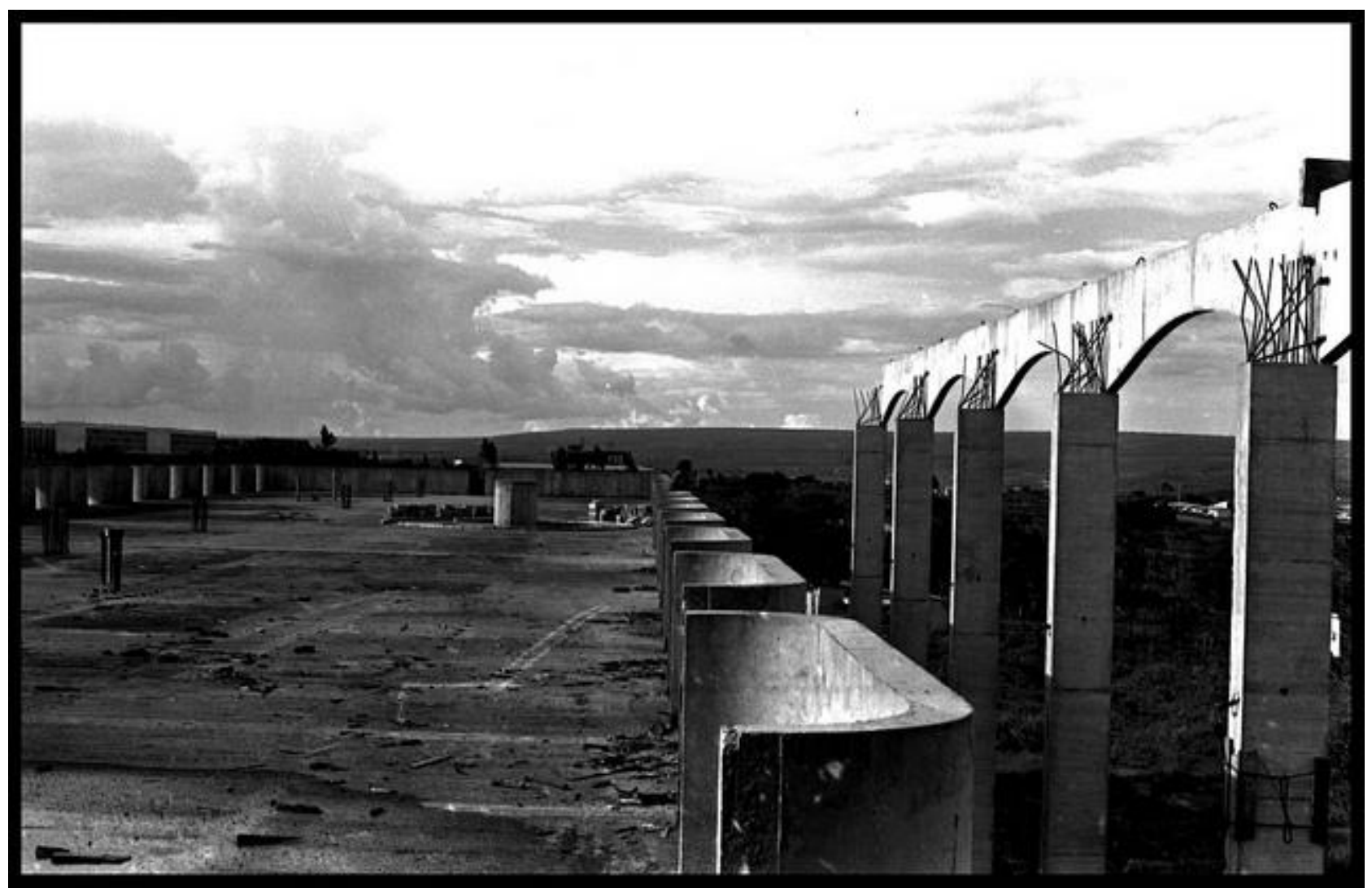

Instituto de Teologia em construção - 1963

$\mathrm{P}$ - E agora? Haveria uma maneira diferente de ver as coisas?

$\mathrm{R}$ - De fato, o Concílio Vaticano apresentou-se como promissor e, por outros motivos, decepcionou. Isto afetou também nossa teologia. Como disse acima, para nós que estudamos na Europa, o fracasso do Concílio, foi uma vitória dos conservadores do Vaticano. Uma coisa era o João XXIII, outra coisa eram os outros cardeais que nem sequer vieram ao Concílio. De certa forma, eles conseguiram, por inércia, anular a vitalidade inovadora do Concílio Vaticano II.

$\mathrm{P}$ - Qual era a expectativa? 
R- Esta era a expectativa relativamente ao Instituto: pensar uma teologia da revolução brasileira. E para completar, não podemos deixar de mencionar outros acontecimentos tais como o encontro de Medelin e a proposta de construirmos uma Teologia da Libertação. Isso mesmo sem esquecer, por exemplo, a contribuição do Leonardo Boff, propondo uma Teologia da Libertação associada a uma mística da fraternidade. Num espírito crítico construtivo, ele nos propõe deixarmos de lado a religiosidade, para falarmos de espiritualidade, também numa perspectiva ecumênica (a começar por um diálogo com o Dalai Lama). Seu texto sobre Espiritualidade $e$ Transcendência não pode passar despercebido de nenhum cristão, hoje. E eu comentava com o Alex [Calheiros de Moura] que a proposta do Boff não deixa de abrir uma perspectiva de diálogo com Espinosa a respeito das relações entre a imanência e a transcendência: nem imanência sem transcendência, nem transcendência sem imanência. (A este propósito, o psicanalista [Wilfred] Bion não deixa de observar que as religiões separam enquanto a mística reúne). Do ponto de vista bíblico, e de uma teologia bíblica, é a retomada do tema do Povo de Deus.

Numa linha parecida com a do Luc Ferry em A Tentação do Cristianismo, o que eu senti como maior tentação do Cristianismo foi o esvaziamento do aspecto revolucionário do Cristianismo a favor de sua institucionalização.

Usando uma outra linguagem, agora no contexto da minha opção pela psicanálise, Bion não hesita em denunciar o que ele chama de "dogmatismo moralista psicótico". Um dos aspectos mais sérios desse conservadorismo-inoperante é a sua rigidez psicótica. Este é um assunto importantíssimo, em função do qual eu me permito sugerir que, se tivermos um novo Instituto de Teologia na UnB, não poderemos deixar de incluir pelo menos um curso de Psicanálise da Experiência Religiosa.

Aliás, a esse respeito, e continuando minha resposta à sua pergunta, há um texto que recomendo a todos, não apenas por causa do título $O$ Deus de cada um, mas por causa do conteúdo e da maneira como o assunto é tratado. Ele foi escrito por Waldemar Falcão com a colaboração de Marcelo Gleiser e frei Betto.

P - Como se deu o final do projeto? Frei Mateus abriu mão do Instituto?

$\mathrm{R}$ - Mais precisamente, a UnB foi forçada a abrir a mão e ceder o prédio do Instituto ao Distrito Federal, que ali instalou sua Secretaria da Educação, não sem antes modificar até mesmo a estrutura do prédio. Se não me engano, isso aconteceu durante a revolução, depois de 64, e depois da saída do Darcy. 


\section{$\mathrm{P}$ - A data precisamente?}

$\mathrm{R}$ - Minha sugestão é que esse ponto seja atentamente pesquisado na história da UnB, para se verificar quando mesmo o Instituto foi desapropriado. 